\title{
Muscle Tissue
}

National Cancer Institute

\section{Source}

National Cancer Institute. Muscle Tissue. NCI Thesaurus. Code C12435.

Tissue responsible for the body movements and the shape and size changes of internal organs. Muscle tissue is composed of specialized contractile cells. There are two types of muscle tissue recognized: striated and smooth muscle. The striated muscle tissue is further subdivided into skeletal, visceral striated, and cardiac muscle. 